Journal of Business and Management Research

ISSN: 2382-5219 (Print); 2467-9267 (Online)

July 2020, Vol. 3, No. 1, pp. 57-74

(C) Kathmandu University

School of Management

DOI: https://doi.org/10.3126/jbmr.v3i1.32029

\title{
Effects of Business Process Reengineering on Organisational Performance in the Food and Beverage Industry in Nigeria
}

\author{
Olubayo Thomas Olajide* \\ Faculty of Management Sciences, Lagos State University. Ojo Lagos State. Nigeria \\ Okunbanjo, Olajide Idowu \\ PhD Student, Department of Business Administration, Olabisi Onabanjo University, Ago-Iwoye, Ogun
}

\begin{abstract}
This study examined effects of business process reengineering (BRP) on organisational performance in the food and beverage industry in Nigeria. The study adopted survey research design and multistage sampling methods. It utilised primary data generated through a questionnaire for the research. Multiple regression analysis was employed to analyse the data. On the hypothesis one, the findings showed that organisational resources and process function have negative and insignificant effect on competitive advantage but innovative thinking has a positive and significant effect on competitive advantage. On the hypothesis two, all the components of business process reengineering (organizational resources, innovative thinking and process function) have positive and significant effect on operational performance. Thus, the study concluded when organizational resources, innovative thinking and process function are combined together as business process reengineering components, they enhance organizational performance in the food and beverages industry in Nigeria. The study suggested that Food and Beverages firms should continue to formulate policies that will encourage innovative ideas from all stakeholders of the organizations in order to continue to achieve competitive advantage and experience sound operational performance. The process function of the organization should continue to be designed and redesigned so that they enjoy smooth operational performance, obtain new resources and upgrade the existing ones so that the firms could achieve competitive advantage. The process function and organization resources need to be evaluated and appraised from time to time to know or detect any lapses that may hinder the firms from attaining their short and long term business goals.
\end{abstract}

Keywords: Business Process Reengineering, Innovative Thinking; Process Function, Organizational Resources; Organizational Performance

\section{Introduction}

Today's business organizations operate in a very volatile business environment, with the globalization making it more increasingly challenging. Operators need to re-engineer existing business processes to remain competitive. Thus, the issue of business process re-engineering (BPR) is topping the agenda of many business organizations in all the industries; the food and beverage inclusive. Organizational performance has been and will continue to be a focal point for researchers and business owners in the $21^{\text {st }}$ century. This warrants all attentions on the end results of organizational activities. Thus, the issue of BPR comes into play, because it has become a proven method to achieve sound organizational performance in terms of operational activities and even competitive advantage.

* Author Email: bayolajide2005@yahoo.com 
BPR involves organization transformation (Herminawaty, 2016), re-evaluation of business models and underlying business process (Akingbade, 2014), to cope with the changing condition. In other words, it emphasizes managing the business process and not necessarily the product per se (Grover, Jeong, Keitinger \& Jeng, 2011). Akam, Okeke, Kekeocha and Onuorah (2018) stated that BPR enables organizations to improve productivity and relationships with customers, and reduce time to launch new products and services in terms of cost, quality, customer satisfaction and shareholders' value by identifying and reengineering the important processes of the firm.

Zigiaris (2000) posited that BPR is a new practice that replaces ineffective organizational processes. This is also shared by Obalum and Okocha (2018). In the view of Nadeem and Ahmad (2016), BPR is a practice that enhances the performance of an organization. This is because BPR challenges conventional processes of an organization and enables an organization to capitalize on substantial developments made in technology and to enhance the capabilities of the employees (Orogbu, Onyeizugbe \& Onuzulike, 2015).

To employ the business process reengineering, certain organizational factors such as financial resource, technology, human resource, innovative rethinking, and process function are required. According to Akam et al. (2018), the advent of globalization brought about the importance of technological resources to business activities. Mwaura (2016) opined that for organizations to convert inputs into outputs, they have to utilize resources and provide products and services to customers and consequently attain their objectives in an efficient and effective manner. Similarly, Musa (2019) stated that a firm's operations include a number of activities such as establishing necessary facilities, creating plant layouts, handling materials, process design, production, materials management, planning control and maintenance work. Re-engineering could be used to solve business challenges facing today's business. However, to compete efficiently it necessitates that Nigerian organizations especially those in food and beverages stay relevant to current organizational practices with business process reengineering as a current organizational practices in the globe (Musa, 2019). The food and beverages industry in Nigeria has been characterized like every other industry with high cost of operations, introduction of new production or operational techniques, competitors from foreign products, unstable government policies as well as erratic power supply among others.

In the last decades, the efficiency of administrative processes has become a major concern for many organizations. With the development of technology and adoption of new managerial techniques, organizational activities have been redefined. Academics and managers now focus their attention on re-engineering process of business activities in the workplace. As the world becomes technologically advanced, with increased global competition, firms in food and beverages industry are left with no choice but to adopt the best organizational practices. Competition is intensifying in terms of price, quality of service; selection and promptness of delivery (Idris, 2011). Thus, organizations have sought for means to reduce cost and improve business efficiency and effectiveness in order to achieve their mission and vision. All these are aimed to satisfy consumers through smooth operational activities that will lead to competitive advantage. In this sense, a good number of organizations in the food and beverage industry, including the Nestle Nigeria Plc, Cadbury Nigeria Plc among others have adopted business process reengineering as a management tool that can revamp their business process in order to achieve the set objectives (Akam et al. 2018). The need to meet up with global standards and business competiveness has kept the firms in the Nigerian food and beverages industry to think of ways and means to level up competition. Thus, it is necessary to see how the adoption of business process practices have affected the routine business activities of food and beverages industry focusing on 
Nestle Nigeria Plc, Cadbury Nigeria Plc, Nigerian Breweries and International Breweries and how it has assisted the firms to have advantage in the sector.

Several studies have confirmed the efficacy of business process reengineering in influencing organizational performance in various sectors like educational sector (Herminawaty, 2016), banking sub-sector (Husameddin \& Mohammad, 2018); Akam et al., 2018); Orogbu, Onyeizugbe \& Onuzulike, 2015); tourist (Naveeda, 2014); and even public sector (Mwaura, 2016). Thus, this study deems it fit to see if the similar results between business process reengineering and organizational performance are found in food and beverage industry in Nigeria. It was further observed that all the studies reviewed failed to include organizational resources (human, physical and financial resources), innovative thinking and process function as proxies for business process reengineering, hence, the need for this study. The general objective of the study is to examine the effect of business process reengineering (Organisation resources; innovative thinking, and process function) on organisational performance (competitive advantage and operational performance) in selected organizations in the food and beverage industry.

\section{Theoretical Foundation}

\section{Resource Based View Theory}

Resource Based View theory was the idea of Penrose in 1959 but expanded by Wernerfelt in 1986. Resource Based View (RBV) theory believes that organization can have a superior performance through its resources and capabilities that are uncommon and difficult to imitate. The RBV emphasizes the firm's resources as the fundamental determinants of competitive advantage and performance.

The resource-based view has been criticized because it is static and does not explain how a specific resource can create a sustainable competitive advantage (Cumberland, 2006). In addition, the concept of firm-specific resources is ambiguous and it is not easy to operationalize measurement items for them (Knott, 2009). The RBV focuses on the role of resources in creating competitive advantage but does not show the relationship between resources and capabilities (Ismail, Rose, Uli, \& Abdullah, 2012).

\section{Dynamic Capability Theory}

David Teece et al (1997) developed dynamic capability theory. Dynamic capabilities theory emphasizes on how organizations integrate, build, and reconfigure their internal and external firmspecific competencies into new competencies that match their turbulent environment (Teece, Pisano \& Shuen, 1997). The dynamic capability theory explains how organizations timely responded to the rapid and flexible external business environment. According to Barreto (2010); Di Stefano, Peteraf and Verona (2010), dynamic capability is the enterprise's potential to systematically solve problems formed by its propensity to sense opportunities and threats, make timely and market-oriented decisions and to change its resource base. The aim of the theory is to understand how firms use dynamic capabilities to create and sustain an operational performance over other firms by responding to and creating environmental changes. Just like every other theory, dynamic capabilities was criticized on the ground that it is difficult to measure empirically (Zahra, Sapienza \& Davidsson, 2006). 


\section{Conceptual Review}

Business Process Re-Engineering (BPR)

BPR refers to achieving a radical breakthrough in performance by breaking away from ineffective business practices and redesigning processes (Husameddin \& Mohammad, 2018). Amer and Kandli (2010) sees BPR as a modern administrative approach that aims to radically and rapidly change organizations by redesigning strategic processes, policies, organizational structures, values and supporting assumptions in a non-traditional way. Akam et al. (2018) posits that BPR implies transformed processes that together form a component of a larger system aimed at enabling organization to empower themselves with contemporary technologies, business solution and innovations. According to Naveerda (2014), BPR is an innovative technique which is used to induce the radical change in the organization set up.

Rigby (2015) noted that BPR involves reduced organizational layers and elimination of unproductive activities in two key areas which are a redesign of functional organizations into crossfunctional teams, and the use of technology to improve data dissemination and decision making. Orogbu et al. (2015) termed BPR otherwise called process innovation, as an effort to redesign the organization for improved efficiency and effectiveness by focusing on the processes used in daily operations rather than on the traditional functions performed by the business.

BPR is defined as the total transformation of a business, an unconstrained reshaping of all business processes, technologies and management systems, as well as organizational structure and values, to achieve quantum leaps in performance throughout the business (Naveerda, 2014). BPR is the process of analyzing and redesigning workflows and business processes within an organization. Business process is a set of tasks logically related and performed to achieve the business results set. BPR is the analysis and redesign of workflow within the company. BPR is a method promoting changes and introducing new process and new style in working. BPR introduces different elements for a change (Herminawaty, 2016). Mwaura (2016) defined BPR as involving the act of rethinking and redesigning the way business operations work in order to better achieve the organization's mission and cut costs. According to Kapoor (2011), BPR helps to improve efficiency, reduces the time lag between different operations, cost reduction, creation of meaningful responsibilities for employees etc

Musa (2019); Orogbu et al. (2015) identified innovative rethinking, process function and radical change as the dimensions of BPR. Akingbade (2014) employed only organization resources as dimension of BPR. Thus, this study sees dimensions of business process reengineering (BPR) as organizational resources, innovative thinking and process function.

\section{Organizational Resources}

This involves technological resources, human resources, and financial resources. Human resource consists of the values, attitudes, and habits of the people in the organization, in addition to the leadership that motivates people to display their potential in the organization (Tarus \& Sitienei, 2015). Technological resource is a firm's ability to use its skills to produce technology and its technological knowledge in replying its customers' needs and wants, and even, for predicting them (Izadi \& Ahmadian, 2018; Duygu, 2015). Urban and Heydenrych (2015) asserted that technology resource gives an organization the advantage for the consumers to prefer their products and services as a result of technological superiority. Financial resource refers to funds which may come from the family in business, extended networks, and from commercial banks or other financial institutions or equity infusion from existing source (Coleman, 2007). In this context, it is referred to as funds from 
commercial banks, retained profits and other means of finance available for an organization. Thus, according to White, Maru and Boit (2015), financial resource can be sources from formal and informal sources.

\section{Innovative Thinking}

Innovation thinking is considered as the valuable asset so that firms can attain and sustain a competitive advantage and in the implementation of the entire strategy (Rajapathirana \& Hui, 2017). The capability of innovation facilitates firms to introduce new products quickly and adopt new systems. Innovation thinking is the idea to developing new products that satisfies market needs. The study sees innovative thinking as the capacity of applying appropriate process technologies in producing new products to meet the demand of the market.

\section{Process Function}

Process function includes the modification of tools or equipment, and operational procedures, and requires the ability to transform knowledge into skill across the entire process. Process function is determined by previous investment in knowledge that is either internal or external, and involves choosing the technical activity to exploit opportunities (Widya-Hasuti, Mardani, Streimikiene, Sharifara \& Cavallaro, 2018). Process function is therefore seen as the role play by each process involve in organizational activities

\section{Organizational Performance}

There are many definitions of organizational performance by different authors but this study adopted "performance is the end result of activities and includes the actual outcomes of the strategic management process". However, performance is defined by Niculescu and Lavalette (2009) as a state of competitiveness of the economic entity, reached by a level of efficiency and productivity that assures a sustainable presence on the market. Organizational performance means to reach the strategic objectives (Alrubaiee, Aladwan, Joma, Idris, \& Khater 2017). According to Chigozie, Aga and Onyia (2018), organizational performance is the aggregated final products of all the organization's work procedures and exercises. According to Murty and Chowdary (2018), organizational performance is the results obtained by the entity in relation to resources used.

Several studies (Eze 2019; Adeoye 2019; Olajide 2019; Okunbanjo 2016 etc) had measured organizational performance with different constructs of financial and non-financial dimensions such as profitability, employed net interest margin, return on equity; return on asset, employee turnover, employee performance, employee retention, sales growth, revenue growth etc. but, this study measured organizational performance by competitive advantage and operational performance

\section{Competitive Advantage}

Competitive advantage is when an organization outperforms its competitors from a wide range in time for efficiency purpose (Owusu \& Duah, 2018). Competitive advantage refers to the ability of an organization to formulate and implement strategies to be in a better position than competitors through better utilization of the technical, physical, financial and organizational capabilities and resources that enable it to design and implement its competitive strategies (Alamri, 2018). Ovidijus (2013) asserted that competitive advantage means superior performance relative to other competitors in the same industry or superior performance relative to the industry average. The term competitive advantage refers to the ability gained through attributes and resources to perform at a higher level than others in 
the same industry or market (Orga, Nnadi \& Emeh 2018). Alamri (2018); Daru (2018); Sachitra (2017); Sachitra, Chong and Khin (2016); Brem, Maier, and Wimschneider (2016); Diab, (2014) viewed competitive advantage from cost dimension, quality dimension, flexibility dimension, delivery dimension and innovation dimension of competitive advantage. Thus, this study sees competitive advantage as an organization's superior performance over its rival.

\section{Operational Performance}

Operational performance refers to the performance related to organizations' internal operation, such as productivity, product quality and customer satisfactions (Feng, Terziovski \& Samson, 2008). Manikas and Terry (2010) referred to operational performance as the ability to measure the outcomes of an organization's processes. Furthermore, operational performance can be defined as the non-economic aspects of an organization's social and societal relationships and competitive success factors that influence the efficiency of its operations (Luo, Huang \& Wang, 2012). Operational performance in this study is therefore defined as smooth internal process of organizational activity.

\section{Empirical Review}

Husameddin and Mohammad (2018) used a qualitative research approach in their study on an overview of the BPR in higher education and concluded that business process reengineering is the only aspect that stands between higher education institutions and disaster in this fast-changing world. Akam, Okeke, Kekeocha and Onuorah (2018) investigated resources of BPR and revealed using the regression analysis that financial resources have higher significant effect on the performance in manufacturing firms in Nigeria than other resources. Similarly, Ogbo, Attah, Ewurum and Ugbam (2015) looked at BPR in the deposit money banks' performance and demonstrated that a significant and positive relationship existed between corporate restructuring and competitive advantage. Herminawaty (2016); Nadeem and Ahmad (2016); Eke and Achilike (2014); Akingbade (2014) Naveeda (2014); Ringim, Razalli and Hasnan (2012); Ozcelik (2010); Sidikat and Ayanda (2008); Adeyemi and Aremu (2008) revealed that BPR has positive and significant effect on organizational performance

Mohammad and Elaheh (2014) investigated on the effect of BPR factors in organizational agility in ports and maritime organizations in Iran. The study used Path Analysis with partial standardized regression coefficient to find that leadership and empowerment variables had the most effect on organizational agility. Magutu, Nyamwange and Kaptoge (2010) investigated BPR and competitive advantage and established that the Wrigley Company gained competitive advantage by implementing business process reengineering. Abdi, Zarei, Vaisy and Parvin (2011) carried out a conceptual research on innovation models and business process redesign. It was based on the innovation mode using Dubin's methodology. This innovation concept makes a new environment that drives employee to innovate and look forward to new processes

BPR and organizational performance of selected automobile firms in Southeast of Nigeria was conducted by Orogbu, Onyeizugbe and Onuzulike (2015). The authors' used Pearson's product moment correlation for data analysis and $\mathrm{Z}$ test to reveal that there is positive relationship between process redesign and employee satisfaction, work process innovation influences employee retention and that custom excise duties influence organizational success. Obalum and Okocha (2018) examined business process reengineering and corporate performance of deposit money banks in Rivers State. The Spearman Rank Order Correlation Coefficient statistical instrument discovered a positive connection between business process re-engineering and corporate performance of deposit money banks. Mwaura 
(2016) investigated BPR and operational performance at Nairobi City County. In the study information and communication technology (ICT) infrastructure, leadership, staff involvement and customer focus were the proxies for BPR while operational performance was proxied by effectiveness and efficiency. The Chi-Square analysis revealed that there was a statistically significant association between BPR and operational performance.

From the review of the past studies, it was observed that studies across the globe had employed different proxies for BPR; for example, Product quality, Process management, Information technology usage, process design, innovation, change management, staff involvement, innovative thinking, process function, organisational resources (Akam et al 2018; Obalum \& Okocha 2018; Nadeem \& Ahmad 2016; Mwuara 2016; Orogbu et al 2015; Asamare, 2012). Thus, this study adopted organisational resources, innovative thinking, and process function. In addition, it was observed that proxies of BPR employed by these studies have significant influence on firm performance but most of these studies reviewed were not conducted in food and beverages industry in Nigeria. The studies that were done in Nigeria focused on automobile industry, banking industry, manufacturing firms (Akam et al., 2018; Ogbo et al 2015; Adeyemi \& Aremu, 2008). Akingbade (2014) studied BPR in the food and beverages industry which did not include the variables that this present study intended to capture. Furthermore, most studies asserted that BPR enhance firm performance; this study wants to confirm if similar results will be arrived when tested in Nigerian food and beverage industry.

\section{Hypotheses of the Study}

$\mathrm{H}_{1}$ : Business process reengineering components (Organisation resources; innovative thinking, and process function) do not have significant effect on the firms' competitive advantage in Nigerian food and beverages industry

$\mathrm{H}_{2}$ : Business process reengineering components (Organisation resources; innovative thinking, and process function) do not have significant effect on firms' operational performance in Nigerian food and beverages industry

\section{Methods}

Survey research design was adopted in this study to generalize the findings of the study from the sampled population. This research design has been used by previous studies such as Olajide (2019); Eze (2018). The population for the study was full time staff in big three food related producing firms and two beverages producing industry in Nigerian: Nestle Nigeria Plc, Nigerian Breweries Plc, Cadbury Nigeria Plc and International Breweries. The number of full time staff of the selected firms is 2,187, 2,987, 550, and 2,245 for Nestle Nigeria Plc, Nigerian Breweries Plc, Cadbury Nigeria Plc and International Breweries respectively (Firms' annual reports, 2018). This makes the total population for the study to be 7969 .

Taro Yamane formula was employed to determine the sample size for the study.

$$
\begin{aligned}
& n=N \\
& \text { Where } \mathrm{n} \quad=\quad \text { Sample size }
\end{aligned}
$$




$$
\begin{aligned}
& \mathrm{n}=\frac{7969}{\mathrm{e}}=\frac{\begin{array}{l}
\text { Population of the study } \\
\text { precision of sampling error }(0.05)
\end{array}}{\mathrm{n}=} \\
& n=400
\end{aligned}
$$

Due to the stratification of the sampled firms' population, the below formula was adopted to proportionally determine the individual firms sample size

$$
C n=\frac{C N}{N * 1} n
$$

Where $\mathrm{Cn}=$ Estimated participant unit allocation per tertiary institution; $\mathrm{CN}=$ Population per sampled firms; $\mathrm{N}=$ Total population of the study and $\mathrm{n}=$ Sample size of the study.

\section{Nestle Nigeria Nigerian Breweries Cadbury Nigeria International Breweries}

$$
\begin{array}{lllr}
C n=\frac{2187}{7969} * 400 & C n=\frac{2983}{7969} * 400 & C n=\frac{550}{7969} * 400 & C n=\frac{2249}{7969} * 400 \\
C n=0.43 * 400=110 & C n=0.37 * 400=150 & C n=0.07 * 400=28 & C n=0.28 * 400=112
\end{array}
$$

The study used multistage sampling method (Stratified and simple sampling techniques) because the population are divided into groups to ascertain for each strata before the administration of the questionnaire. The data for the study was collected through structured questionnaires administered to the staff of the selected firms. The questionnaire was grouped into part A and Part B. Part A covered personal details of the respondents while part B covered items on the variables employed to achieve the objectives of the study. The variables were organizational resources, innovative thinking, process function, operational performance and competitive advantage. The study adapted Orogbu et al. (2015) items on process function; Akam et al. (2018) items on organizational resources; Rajapathirana and Hui (2018) items on innovative thinking and operational performance; and Omwoyo (2016) items on competitive advantage. Each variable has 7 items in the questionnaire. The items for each variable were ranked using 6-point rating scale, where Strongly Agree =6, Agree=5, Partially Agree=4, Fairly Disagree $=3$, Disagree $=2$, Strongly Disagree $=1$. The study employed multiple regressions as data analysis method. 


\section{Results}

Table 1 shows the response rate of the administered questionnaires. It shows that there is high rate or percentage of returned questionnaires which is good to achieve the objectives of the study. The total questionnaires returned was 311 which represented 77.6 percent of the total questionnaire administered.

Table 1

Respons Rate

\begin{tabular}{llll}
\hline Firms & $\begin{array}{l}\text { No of Questionnaire } \\
\text { Administered }\end{array}$ & $\begin{array}{l}\text { No of Returned } \\
\text { Questionnaire }\end{array}$ & $\begin{array}{l}\text { Percentage of } \\
\text { Questionnaire }\end{array}$ \\
\hline Nestle Nigeria Plc & 110 & 81 & 73.6 \\
Nigerian Breweries Plc & 150 & 124 & 82.7 \\
Cadbury Nigeria Plc & 28 & 28 & 100 percent \\
International Breweries Plc & 112 & 78 & 69.6 percent \\
\hline Total & 400 & 311 & 77.6 percent \\
\hline
\end{tabular}

Source: Research Study, 2019

\section{Reliability Test of the Data}

The research instrument was tested using Cronbach Alpha to ascertain the rate of the internal consistency in the data

Table 2

Reliability Results for the Variables

Organization Resources:

Cronbach Alpha

.729

Items

1. There is adequate technology infrastructure and they are used to achieve organizational objectives

2. My organization facilities are maintain at from time to time

3. Organization has adequate equipment and structures in good condition to meet its mandate

Innovative Thinking:

1. My organization allows and encourages unpopular ideas in the activities within the organization

2. Innovative rethinking strengthens employees' ability to perform tasks in an efficient manner through knowledge sharing

3. My organization does develop new products to meet the public demand or needs

4. The management always come up with new ideas of production processes and service delivery 
Process Function:

1. My organization has a system that is open to change in its methods of operation

2. My organization has been able to simplify its methods towards ensuring that results are achieved.

3. My organization always reinvented the way work is being done to meet the current business demand

Competitive Advantage:

1. The knowledge management capability in my organization would be difficult and expensive for rivals to duplicate

2. My organization ensures frequent product development

3. My organization has gained more customer patronage in the market1

Operational Performance:

1. My organization is flexible to environmental changes that can affect the business operations

2. My organization does experience shortage of organizational tools to carry out its routine activities

Table 2 displayed the Cronbach Alpha results of the variables with the selected items. It is revealed that organization resources, innovative thinking, process function, competitive advantage, and operational performance had reliability values of .729; .728; .728; 731 and .722, respectively. The values are greater than 0.70 which implies that the data are reliable to achieve the objectivity of the study.

Table 3

Correlation Matrix: Business Process Re-Engineering Components and Competitive Advantage

\begin{tabular}{lllll}
\hline & $\begin{array}{l}\text { Competitive } \\
\text { Advantage }\end{array}$ & $\begin{array}{l}\text { Organizations' } \\
\text { Resources }\end{array}$ & $\begin{array}{l}\text { Innovative } \\
\text { Thinking }\end{array}$ & $\begin{array}{l}\text { Process } \\
\text { Function }\end{array}$ \\
\hline Competitive Advantage & 1 & & & \\
Organizations' Resources & .081 & 1 & & \\
Innovative Thinking & .491 & .237 & 1 & \\
Process Function & .034 & .065 & .085 & 1 \\
\hline
\end{tabular}

Dependent Variable: Competitive Advantage

Source: SPSS Output. 2019

Table 3 revealed the correlation matrix among the BPR components (organizations' resources, innovative thinking, process function and competitive advantage). It is seen that BPR components have positive relationship with competitive advantage. But innovative thinking has the highest correlation value with competitive advantage. All correlations are significant significant $(\mathrm{p}<.05)$. 
Business Process Reengineering and Organizational Performance 67

Table 4

Business Process Re-Engineering Components and Operational Performance

\begin{tabular}{lllll}
\hline & $\begin{array}{l}\text { Operational } \\
\text { Performance }\end{array}$ & $\begin{array}{l}\text { Organizations' } \\
\text { Resources }\end{array}$ & $\begin{array}{l}\text { Innovative } \\
\text { Thinking }\end{array}$ & $\begin{array}{l}\text { Process } \\
\text { Function }\end{array}$ \\
\hline Operational Performance & 1 & & & \\
Organizations' Resources & .371 & 1 & & \\
Innovative Thinking & .324 & .237 & 1 & \\
Process Function & .150 &.-065 & .085 & 1 \\
\hline
\end{tabular}

Dependent Variable: Operational Performance

Source: SPSS Output. 2019

Table 4 shows the correlation matrix among BPR components (organizations' resources, innovative thinking, process function and competitive advantage) and operational performance of selected firms in Nigerian food and beverages industry. It is found that all the components of BPR have positive relationship with operational performance but organizational resources have the highest correlation value with operational performance. All correlations are significant $(\mathrm{p}<.05)$.

Regression Analysis

Hypothesis one: Business process reengineering components (organizations' resources; innovative thinking, and process function) do not have significant effect on the firms' competitive advantage

Table 5

Business Process Re-Engineering Components and Competitive Advantage

\begin{tabular}{lllll}
\hline & $\beta$ & Std & t-value & P-value \\
\hline Organizations' Resources & -.034 & .045 & -1.757 & .049 \\
Innovative Thinking & .526 & .054 & 9.759 & .000 \\
Process Function & -.006 & .026 & -.219 & .827 \\
$\mathrm{R}^{2}=0.243$ & & & & \\
$\mathrm{P}-$ value=0.000 & & & & \\
F-Value=32.776 & & & & \\
\hline
\end{tabular}

Dependent Variable: Competitive Advantage

Source: SPSS Output. 2019

The multiple regression results of hypothesis one that business process reengineering components (organizations' resources, innovative thinking and process function) does not have significant effect on firms' competitive advantage in Nigerian food and beverages industry showed that 24.3 percent $\left(R^{2}=.243\right)$ of the variations in competitive advantage is explained by organizational resources, innovative thinking and process function as components of business process re-engineering. The results showed that organizations' resources has a negative and significant effect on firms' competitive advantage $(\beta=-0.034, \mathrm{t}=-1.757, \mathrm{p}$-value $=.045)$. The results indicated that innovative thinking has a positive and significant effect on competitive advantage $(\beta=0.526, t=9.759, p$-value $=.000)$. Also, the results showed that process function has a negative and insignificant effect on competitive advantage. When combined all the components together, the overall $\mathrm{p}$-value of the multiple regression revealed that there is significant effect of business process reengineering components on competitive advantage 
of the selected firms in Nigerian food and beverage industry. Thus, the study rejects the null hypothesis.

Hypothesis two: Business process reengineering components (organizations' resources; innovative thinking, and process function) does not have significant effect on firms' operational performance

Table 6

Business Process Re-engineering Components and Operational Performance

\begin{tabular}{lllll}
\hline & $\beta$ & Std & t-value & P-value \\
\hline Organizations' Resources & .389 & .065 & 5.983 & .000 \\
Innovative Thinking & .346 & .077 & 4.468 & .000 \\
Process Function & .094 & .046 & 2.806 & .048 \\
$\mathrm{R}^{2}=.207$ & & & & \\
F-Value=26.571 & & & & \\
\hline
\end{tabular}

Dependent Variable: Operational Performance

Source: SPSS Output. 2019

Table 6 displayed the multiple regression results between business process re-engineering components and operational performance of the selected firms in Nigerian foods and beverages. The table showed that 20.7 percent $\left(R^{2}=0.207\right)$ of the changes in operational performance is caused by business reengineering process (organizations' resources, innovative thinking and process function). The results indicated that organizations' resources, innovation thinking and process function have positive and significantly influence on operational performance of the selected firms $(\beta=.389, \mathrm{t}$ statistic $=5.983, \mathrm{p}$-value $=.000),(\beta=.346, \mathrm{t}$ statistic $=4.468, \mathrm{p}$-value $=.000)$ and $(\beta=.094, \mathrm{t}$ statistic $=$ 2.806 , $\mathrm{p}$-value $=.048$ ) respectively. Also, the overall $\mathrm{p}$-value of the regression results indicated that $\mathrm{p}$ value is less than 0.05 percent significant level. Thus, this study rejects the null hypothesis that Business process reengineering components do not have significant effect on operational performance of firms in Nigerian food and beverages industry.

\section{Discussion}

The objective of this study was to examine BPR and organizational performance, thus, the study did not experience any form of limitations in the methods employed. The findings on hypothesis one showed that organizational resources do not have impact on firms' competitive advantage. This indicated that there are factors to achieving competitive advantage aside from the resources that the firms' possess. It could be that firms in the food and beverages industry are not harnessing the resources they possess towards achieving competitive advantage. According to Musa (2019), when organizations lack the required or needed resources, it will show in their performance. The results of the hypothesis agreed with the findings of Ismail, Rose, Uli and Abdullah (2012) but disagreed with the findings of Ongeti and Machuki (2018); Nganga, Waiganjo and Njeru (2015). Also, the multiple regressions indicated that innovative thinking contributes immensely to firms' competitive advantage. It implied that food and beverages firms introduce innovative products or service as results of innovative thinking. The innovative thinking results to innovation which is why the organizations are able (may) to gain an advantage and contribute grossly to the growth of Nigerian economy. The findings agreed with the results of previous studies, such as Reguia (2014); Urbancová (2013); Adhikari (2011) among other studies. Conversely, the results on process function in the hypothesis implied that the process function of the selected firms has not enhanced the firms to achieve 
competitive advantage. This implied that there is connectivity in the process of carrying out business plans or executive the business plans. The findings are inconsistent with what Orogbu et al. (2015) asserted.

The multiple regression for hypothesis two between business process reengineering (organizations' resources, innovative thinking and process function) and operational performance indicated that organizational resources, innovative thinking and process function of business process reengineering (BPR) have a positive and significant effect on the operational performance of the selected organization in Nigerian food and beverages industry. This implied that there is connectivity among components of business process reengineering that has reflected in the operational activities of the selected firms. It is evidenced that the quality of product, minimization of wastages, speed involving in producing and service offering have been enhanced by business process reengineering components (organizations' resources, innovative thinking and process function). The findings of the hypothesis is consistent with the findings of Obalum et al. (2018); Akingbade (2014).

\section{Implication and Future Research Direction}

Based on the analysis and interpretations in the previous section of the study, it is established that BPR components (organizational resources, innovative thinking and process function) are important in the operational activities of the organisations in Nigerian food and beverages industry. The study asserted that innovative thinking is the only component of business process reengineering that can lead to competitive advantage. Thus, the study concluded when organizational resources, innovative thinking and process function are combined together as business process reengineering components, they enhance organizational performance in the food and beverages industry in Nigeria.

Thus, the study suggested that:

1. Food and Beverages firms should continue to formulate policies that will encourage innovative ideas from all stakeholders of the organizations in order to continue to achieve competitive advantage and experience sound operational performance.

2. The process function of the organization should continue to be designed and to achieve operational efficiency and improved performance as well as obtaining the new resources and upgrading the existing resources so that the firms achieve competitive advantage.

3. The process function and organization resources need to be evaluated and appraised from time to time to know or detect any lapses that will hinder the firms from attaining their short and long terms objectives or business goals.

This study will be useful to the management of organizations in the food and beverages especially in Nestle Nigeria Plc. It will give them the in depth understanding on the necessity of practicing business process re-engineering. This study will be useful and important to the government so as to encourage and establish an institution(s) or formulate polices that will ease the practices of business process re-engineering among firms in the manufacturing sector and every other sectors of the economy. This study will be relevant to academic institutions regarding research and course curriculum. This study will be useful for further research studies on business process re-engineering and related construct or concept to it. Generally, the study will be relevant and significant to the entire public on the important and necessity of business process re-engineering practices. Also, the findings could be extended to organizational changes of small and medium enterprises in Nigeria. 


\section{References}

Abdi, N., Zarei, B., Vaisy, J., \& Parvin, B. (2011). Innovation models and business process redesign. International Business and Management, 3(2), 67-82. DOI:10.3968/j.ibm.1923842820110302.095 Adeoye, I. (2019). Strategic leadership and organizational performance in Nigeria. Ph.D Thesis, Babcock University, Nigeria

Adeyemi, S., \& Aremu, M.A. (2008). Impact assessment of business process reengineering on organizational performance. European Journal of Social Sciences, 7(1), 115-122

Adhikari, B. (2011). Innovation: Tools to create competitive advantage for business. Electronic copy available at: http://ssrn.com/abstract $=1874666$

Akam, G. U., Okeke, M. N., Kekeocha, M. E., \& Onuorah, A. N. (2018). Business process reengineering resources and the performance of quoted brewing firms in Nigeria. Asian Business Research Journal, 3(1), 15-25. DOI: 10.20448/journal.518.2018.31.15.25

Akingbade, W.A. (2014). Business process re-engineering and customer responses in selected food and beverages companies in Lagos State. Review of Public Administration and Management, 3(5), 56-72.

Alamri, A.M. (2018). Strategic management accounting and the dimensions of competitive advantage: Testing the associations in Saudi industrial sector. International Journal of Academic Research in Accounting, Finance and Management Sciences, 8(2), 48-64. DOI: 10.6007/IJARAFMS/v8-i2/4137)

Alrubaiee, L. S., Aladwan, S., Joma, M. H. A., Idris, W. M., \& Khater, S. (2017). Relationship between corporate social responsibility and marketing performance the mediating effect of customer value and corporate image. International Business Research, 10(2), 104-123.

DOI:10.5539/ibr.v10n2p104

Amer, S., \& Kandil, A. (2010). Organizational development. Amman: Dar Al-Fikr Publishers \& Distributors.

Andrew, D.C., \& Stalick, S.K. (1994). Business reengineering: The survival guide. NewJersey: Prentice Hall.

Asmare, E.K. (2012). The effect of business process reengineering on public sector organisation performance (A developing economy context). Ph.D Thesis, RMIT University.

Barreto, I. (2010), Dynamic capabilities: A review of past research and an agenda for the future. Journal of Management 36(1), 256-280. https://doi.org/10.1177/0149206309350776

Brem, A., Maier, M., \& Wimschneider, C. (2016). Competitive advantage through innovation: the case of Nespresso. European Journal of Innovation Management, 19(1), 133-148.

DOI.org/10.1108/EJIM-05-2014-0055

Chigozie, M. P., Aga, C. C., \& Onyia, E. (2018). Effect of human capital development in organizational performance in manufacturing industries in South-East Nigeria. International Journal of Academic Research in Economics and Management Sciences, 7(3), 60-78. DOI: 10.6007/IJAREMS/v7-i3/4378

Coleman, S. (2007). Women-owned firms and growth. Journal of Business and Entrepreneurship, 19(2), 31-47

Cumberland. K. (2006). A resource-based theory of the firm: Knowledge versus opportunism. Organization Science, 7, 477-501.

Daru, M. (2016). Total quality management (TQM): A strategy for competitive advantage. International Journal of Research in IT and Management, 6(9), 51-55. 
Di Stefano, G., Peteraf, M., \& Verona, G. (2010). Dynamic capabilities deconstructed: A bibliographic investigation into the origins, development, and future directions of the research domain. Industrial and Corporate Change, 19(4), 1187-1204

Duygu, S.H. (2015). Multidimensional construct of technology orientation. Procedia - Social and Behavioral Sciences, 195, 1057 - 1065. DOI.ORG/10.1093/ICC/DTQ027

Eisenhardt, K.M., \& Sull, D.N. (2001). Strategy as simple rules. Harvard Business Review, 79(1), 106-116.

Eke, G.J., \& Achilike, A.N. (2014). Business process reengineering in organizational performance in Nigeria banking sector. Academic Journal of interdisciplinary Studied, 3(5), 54-63.

DOI: 10.5901/ajis.2014.v3n5p113

Eze, B.U. (2018). Corporate entrepreneurship and manufacturing firms' Performance. Emerging Markets Journal, 2, 1-17. DOI 10.5195/emaj.2018.146

Feng, M., Terziovski, M., \& Samson, D. (2008). Relationship of ISO 9001:2000 quality system certification with operational and business performance. Journal of Manufacturing Technology Management, 19, 22-37. DOI 10.1108/17410380810843435

Grover, V., Kettinger, W.J., \& Teng, J.T.C. (2011). Business process change in the 21st century. Business and Economic Review, 46(2), 14-18

Hammer, M., \& Champy, J. (1993). Reengineering the corporation. New York: Harper Business

Herminawaty A. (2016). Effects of business process reengineering on organizational performance: Organizational transformation of tour and travel business. Asian Journal of Applied Sciences, $4(1), 1-18$

Husameddin, H., \& Mohammed, A. (2018). An overview of the business process re-engineering in higher education. Asian Journal of Management Sciences \& Education, 7(2), 83-97

Idris, F. (2011). Total quality management (TQM) and sustainable company performances: Examining the relationship in Malaysian firms. International Journal of Bossiness and Society, 12(1), 31-52

Ismail, Z., Masood, S., \& Mehmood, Z. (2012).Factors affecting consumer preferences of international brands over local brands.2nd International Conference on Social Science and Humanity, Singapore

Izadi, S., \& Ahmadian, S. (2018). The effects of strategic orientation and firm competencies on export performance. Revista Publicando, 5(2), 834-857.

Jenatabadi, H.S., \& Ismail, N.A. (2014). Application of structural equation modelling for estimating airline performance. Journal of Air Transport Management, 40, 25-33

K'Obonyo, P. O., \& Gitahi, A.W. (2018). The relationship between organizational resources and firm performance of companies listed on the Nairobi securities exchange. International Journal of Economics, Commerce and Management, 5(5), 540-555

Kapoor, H. K. (2011), Business process reengineering: improving in new strategic directions. California Management Review, 2 93-108.

Knott, P. (2009). Integrating resource-based theory in a practice-relevant form. Journal of Strategy and Management, 2, 163-174. DOI: 10.1108/17554250910965317

Laforet, S. (2011). A framework of organizational innovation and outcomes in SMEs. International Journal of Entrepreneurial Behavior \& Research, 17(4), 380-408. Doi.org/10.1108/13552551111139638

Luo, Y., Huang, Y., \& Wang, S. (2012). Guanxi and organizational performance: A meta-analysis. Chinese Management Studies, 4, 78-82. https://doi.org/10.1111/j.1740-8784.2011.00273.x

Magutu, P.O., Nyamwange, S.O., \& Kaptoge, G.K (2010). Business process reengineering for competitive advantage. African Journal of Business and Management, 1, 1-16 
Manikas, I., \& Terry, L. (2010). A case study assessment of the operational performance of a multiple fresh produce distribution centre in the UK. British Food Journal, 112, 653-667.

Mohammad, M. M., \& Elaheh, M. (2014). The effect of business process re-engineering factors on organizational agility using path analysis: Case study of Ports \& Maritime Organization in Iran. Asian Economic and Financial Review, 4(12) 114-121

Murty, A. N., \& Chowdary, R. E. (2018). Effective of interest rates changes on profitability of banking industry in India (An empirical research on the profitability performance of Nationalized Banks in India). Journal of Business and Management, 20(2), 82-91. DOI: 10.9790/487X-2002068291

Musa, K. (2019). Effects of business process re-engineering on firms' performance. M.Sc Thesis, Lagos State University, Ojo

Mwaura, I. M. (2016). Business process re-engineering and operational performance at Nairobi City County. MBA Thesis, University of Nairobi, Kenya.

Nadeem, M., \& Ahmad, R. (2016). Impact of business process reengineering on the performance of banks in Pakistan. Business and Economics Journal, 7(1), 1 -3. . doi:10.4172/2151-6219.1000202

Nganga, L. W., Waiganjo, E. W., \& Njeru, A. W. (2018). Influence of organizational resources portfolio on organizational performance in tourism government agencies in Kenya. International Journal of Business and Commerce, 6(4), 1-17

Niculescu, M., \& Lavalette, G. (2009). Strategic growth. București: Economică Publishing House Nuryakin, N. (2018). Competitive advantage and product innovation: key success of Batik SMEs marketing performance in Indonesia. Academy of Strategic Management Journal, 17(2), 1-17

Obalum, A.I., \& Okocha, B. F. (2018). Business process reengineering and corporate performance of deposit money banks in Rivers State. International Journal of Business Systems and Economics, 12(1), 91-104

Ogbo, A. I., Attah, E. Y., Ewurum, U. J., \& Ugbam, C. O. (2015). Business process reengineering and performance of commercial banks in North Central Nigeria. International Journal of Contemporary Applied Sciences, 2(10), 1-13

Okunbanjo, O. I. (2016). Leadership style, employee empowerment and organizational performance in Nigerian banking industry. M.Sc Thesis, Lagos State University.

Olajide, O. T. (2018). Entrepreneurship skill development, government support and SMEs growth. Journal of Entrepreneurship Innovation, 9(1), 1-8

Olajide, O. T. (2019). Intellectual capital and firm performance in Nigerian insurance industry. A paper presented at Faculty of Management Sciences, Lagos State University

Olajide, O. T., Asaolu, T., \& Jegede, C.A (2011). The impact of financial sector reforms on banks performance in Nigeria. The International Journal of Business and Finance Research, 5(1), 53-63

Omwoyo, R. M. (2016). Effects of generic strategies on the competitive advantage of firms in Kenya's airline industry: A survey of selected airlines. M.Sc Dissertation, United States International University, Africa

Ongeti, W. J., \& Machuki, V. N. (2018). Organizational resources and performance of Kenyan State Corporations. European Scientific Journal, 14(34), 91-112

Orga, J.I., Nnadi, C.S., \& Emeh, N. C. (2018). The role of knowledge management on the competitive advantage of food and beverage firms in South East Nigeria. Scholars Journal of Economics, Business and Management, 5(7), 612-622. DOI: 10.21276/sjebm.2018.5.7.8

Orogbu, O. L., Onyeizugbe, C.U., \& Onuzulike, N. F. (2015). Business process reengineering and organizational performance of selected automobile firms in Southeast of Nigeria. European Journal of Business, Economics and Accountancy, 3(5), 2056-2078

Ovidijus, J. (2013). Competitive advantage. Http://wwww.strategicmanagementinsight.com 
Owusu, P. A., \& Duah, H. K. (2018). Evaluating total quality management as a competitive advantage tool in mobile telecommunication service in Ghana. European Journal of Research and Reflection in Management Sciences, 6(1), 9-32

Ozcelik, Y. (2010). Do business process reengineering projects payoff: Evidence from the United States. International Journal Project Management, 28, 7-13

Rajapathirana, R. P., \& Hui, Y. (2017). Relationship between innovation capability, innovation type, and firm performance. Journal of Innovation \& Knowledge, 3, 44-55. Doi.org/10.1016/j.jik.2017.06.0022444

Ranjith, V. (2016). Business models and competitive advantage. Procedia Economics and Finance, 37 , 203-207. DOI: 10.1016/s2212-5671

Reguia, C. (2014). Product innovation and the competitive advantage. European Scientific Journal, 1,140-157

Reijonen, H., Hirvonen, S., Nagy, G., Laukkanen, T., \& Gabrielsson, M. (2015). The impact of entrepreneurial orientation on business to business branding and business growth in emerging markets. Industrial Marketing Management, 51, 35-46. http://dx.doi.org/10.1016/j.indmarman.2015.04.016 0

Rigby, D.K. (2015). Management tools: An executive's guide. Boston: Bain \& Company, Inc. Ringim, K.

J., Razalli, M. R. \& Hasnan, N. (2012). Moderating effect of information technology (IT) capability on the business process reengineering factors and organizational performance of bank. African Journal of Business Management, 6(16), 5551-5567. Doi.Org/10.5897/Ajbm11.2792

Sachitra, V. (2017). Review of competitive advantage measurements: Reference on agribusiness sector. Journal of Scientific Research \& Reports, 12(6), 1-11. DOI: 10.9734/JSRR/2016/30850

Sachitra, V., Chong S.C., \& Aye, A. K. (2016). Sources of competitive advantage measurement in the minor export crop sector in Sri Lanka: Result from pilot study. Asian Journal of Agricultural Extension, Economics, and Sociology, 12(2), 1-15. DOI: 10.9734/JSRR/2016/30850

Sidikat, A., \& Ayanda, A.M. (2008). Impact assessment of business process reengineering on organizational performance. European Journal of Social Science, 7(1), 16-29

Suresh, D., \& Jaleel, A. N. (2015). Impact of employee empowerment on organisational performance: A case of automobile industry in Chennai city of Tamil Nadu in India. International. Journal of Innovative Science, Engineering \& Technology, 2(4), 21-31

Tarus, D., \& Sitienei, E. (2015). Intellectual capital and innovativeness in software development firms: The moderating role of firm size. Journal of African Business, 16, 48-65. Doi.Org/10.1080/15228916.2015.1061284

Teece, D. T., Pisano, G., \& Shuen, A. (1997). Dynamic capabilities and strategic management. Strategic Management journal, 6, 509-533.

Urban, B., \& Heydenrych, J. (2015). Technology orientation and effectuation - links to firm performance in the renewable energy sector of South Africa. South African Journal of Industrial Engineering, 26(3), 125-136. Doi.org/10.7166/26-3-1039

Urbancová, H. (2013). Competitive advantage achievement through innovation and knowledge. Journal of Competitiveness, 5(1), 82-96. DOI: 10.7441/joc.2013.01.06

White, M., Maru, L., \& Boit, R.J. (2015). Financial resource as drivers of performance in small and micro enterprises in service retail sector: A case of Eldoret Municipality, Uasin Gishu Country, Kenya. Global Journal of Human-Social Science, 15(4), 1-12

Widya-Hasuti, A., Mardani, A., Streimikiene, D., Sharifara, A., \& Cavallaro, F. (2018). The role of process innovation between firm-specific capabilities and sustainable innovation in SMEs: Empirical evidence from Indonesia. Sustainability, 10, 22-44. ; Doi: 10.3390/su10072244 
74 O. Olajide

Zahra, S. A., Sapienza, H. J., \& Davidsson, P. (2006). Entrepreneurship and dynamic capabilities: A review, model and research agenda`. Journal of Management Studies, 43(4), 917-955. Doi.Org/10.1111/J.1467-6486.2006.00616.

Zigiaris, S. (2000). Business process re-engineering. Report Produced for the EC Funded Project. Innoregio 